\title{
CORRECTION
}

View Article Online

View Journal I View Issue

\section{Correction: The effect of an ionic liquid on the rate of reaction at a phosphorus centre}

Cite this: NewJ. Chem., 2015, 39, 1525

DOI: $10.1039 / c 4 n j 90052 a$

www.rsc.org/njc
Bradley J. Butler and Jason B. Harper*

Correction for 'The effect of an ionic liquid on the rate of reaction at a phosphorus centre' by Bradley J. Butler et al., New J. Chem., 2015, DOI: 10.1039/c4nj01224k.

In Tables 3 and 5, the units for entropy are incorrectly listed as $\mathrm{kJ} \mathrm{mol}^{-1}$. The correct unit is $\mathrm{J} \mathrm{K}^{-1} \mathrm{~mol}^{-1}$, and the correct tables are shown below.

Table 3 Activation parameters for the ethanolysis of diethyl chlorophosphate at different mole fractions of $[b m i m]\left[\left(\mathrm{CF}_{3} \mathrm{SO}_{2}\right)_{2} \mathrm{~N}\right]$ in ethanol- $d_{6}$

\begin{tabular}{lll}
\hline$\chi[\mathrm{bmim}]\left[\left(\mathrm{CF}_{3} \mathrm{SO}_{2}\right)_{2} \mathrm{~N}\right]$ & $\Delta H^{\ddagger} / \mathrm{kJ} \mathrm{mol}^{-1 a}$ & $\Delta S^{\ddagger} / \mathrm{J} \mathrm{K}^{-1} \mathrm{~mol}^{-1 a}$ \\
\hline 0 & $62 \pm 2$ & $-201 \pm 7$ \\
0.31 & $47 \pm 2$ & $-238 \pm 8$ \\
0.72 & $44 \pm 3$ & $-253 \pm 11$ \\
${ }^{a}$ Uncertainties quoted are derived from the fit of the linear regression. &
\end{tabular}

Table 5 Activation parameters in the presence of the salts $[\mathrm{bmim}]\left[\left(\mathrm{CF}_{3} \mathrm{SO}_{2}\right)_{2} \mathrm{~N}\right]$, [bmim] $[\mathrm{Cl}]$ and lithium bis(trifluoromethylsulfonyl)imide in ethanol- $d_{6}$ for the ethanolysis of diethyl chlorophosphate

\begin{tabular}{lll}
\hline$\chi_{\text {salt }}$ & $\Delta H^{\ddagger} / \mathrm{kJ} \mathrm{mol}^{-1 a}$ & $\Delta S^{\ddagger} / \mathrm{J} \mathrm{K} \mathrm{mol}^{-1} a$ \\
\hline 0 & $62 \pm 2$ & $-201 \pm 7$ \\
$0.21[\mathrm{bmim}]\left[\left(\mathrm{CF}_{3} \mathrm{SO}_{2}\right)_{2} \mathrm{~N}\right]$ & $46 \pm 2$ & $-243 \pm 7$ \\
$0.24[\mathrm{Li}]\left[\left(\mathrm{CF}_{3} \mathrm{SO}_{2}\right)_{2} \mathrm{~N}\right]$ & $76 \pm 5$ & $-180 \pm 16$ \\
$0.22[\mathrm{bmim}][\mathrm{Cl}]$ & $52 \pm 1$ & $-215 \pm 4$ \\
${ }^{a}$ Uncertainties quoted are derived from the fit of the linear regression. & 4
\end{tabular}

The Royal Society of Chemistry apologises for these errors and any consequent inconvenience to authors and readers. 